\title{
Analysis of Low-Power Steam Turbine With One Extraction for Marine Applications
}

\section{Analiza parne turbine male snage s jednim oduzimanjem pare za primjenu u pomorstvu}

\author{
Vedran Medica-Viola \\ University of Rijeka \\ Faculty of Engineering \\ e-mail:vmedica@riteh.hr
}

\author{
Vedran Mrzljak \\ University of Rijeka \\ Faculty of Engineering \\ e-mail: vedran.mrzljak@riteh.hr
}

\author{
Nikola Anđelić \\ University of Rijeka \\ Faculty of Engineering \\ e-mail: nandelic@riteh.hr
}

\author{
Maro Jelić \\ University of Dubrovnik \\ Maritime Department \\ e-mail:maro.jelic@unidu.hr \\ DOI 10.17818/NM/2020/2.1 \\ UDK 621.125:536 \\ Original scientific paper / Izvorni znanstveni rad \\ Paper accepted / Rukopis primljen: 29. 11. 2019.
}

\section{Summary}

The paper presents thermodynamic (energy and exergy) analysis of low-power steam turbine with one extraction for marine applications. Analyzed steam turbine is divided in two parts - High Pressure (HP) part before steam extraction and Low Pressure (LP) part after steam extraction. Analysis shows that HP turbine part produces the majority of cumulative turbine power and consequentially has higher mechanical, energy and exergy losses when compared to LP turbine part. Regardless of heavier operating conditions, LP turbine part has higher efficiencies and lower specific losses (in both energy and exergy analysis) when compared to HP turbine part. Whole analyzed turbine has energy and exergy efficiencies equal to $62.84 \%$ and $65.58 \%$, while energy and exergy turbine losses are $696.74 \mathrm{~kW}$ and $618.50 \mathrm{~kW}$. Cumulative produced power at the turbine shaft outlet is equal to $1178.40 \mathrm{~kW}$. Steam extraction which divides analyzed turbine on HP and LP part can deliver a notable amount of heat to any marine heat consumer, what represents a significant advantage of observed turbine in comparison with similar low-power marine steam turbines which usually does not have steam extractions.

\section{Sažetak}

Uradujeprikazanatermodinamička (energijskaieksergijska) analizaparneturbinemale snage s jednim oduzimanjem pare za primjenu u pomorstvu. Analizirana parna turbina podijeljena je u dva dijela - visokotlačni dio (HP) prije oduzimanja pare i niskotlačni dio (LP) nakon oduzimanja pare. Analiza pokazuje da visokotlačni dio proizvodi većinu snage turbine i posljedično ima veće mehaničke, energijske i eksergijske gubitke u usporedbi s niskotlačnim dijelom turbine. Bez obzira na teže radne uvjete, niskotlačni dio turbine ima veću učinkovitost i manje specifične gubitke (u energijskoj i eksergijskoj analizi) u usporedbi s visokotlačnim dijelom turbine. Cijela analizirana turbina ima energijsku i eksergijsku učinkovitost jednaku $62.84 \%$ i $65.58 \%$, dok su gubici energije i eksergije turbine 696.74 kW i 618.50 kW. Kumulativna proizvedena snaga na izlazu turbinskog vratila jednaka je $1178.40 \mathrm{~kW}$. Oduzimanjem pare kojim se analizirana turbina dijeli na visokotlačni i niskotlačni dio može se isporučiti značajna količina topline bilo kojem potrošaču topline u pomorskoj industriji, što predstavlja značajnu prednost promatrane turbine u usporedbi sa sličnim brodskim parnim turbinama male snage koje obično nemaju oduzimanje pare.

\section{KEY WORDS}

steam turbine

low-power

steam extraction

marine applications

thermodynamic analysis

\section{INTRODUCTION / Uvod}

Steam turbines are widely used components in power plants for electricity production all over the world [1, 2]. Such steam turbines are high-power, complex components which consist of several cylinders and a number of turbine stages in each cylinder $[3,4]$. Small, low-power steam turbines are often used in such power plants for the drive of several power consumers, e.g. water pumps [5].

In marine applications, steam turbines can be used in various combinations and in various systems. The most common usage of steam turbines in marine applications is in the engine rooms of the LNG (Liquefied Natural Gas) carriers, which still has the steam propulsion system as a dominant one [6, 7]. In such marine steam propulsion system all of the steam turbines (main turbine and auxiliary) are low-power turbines (main turbine maximum power usually did not exceed $30 \mathrm{MW}$, while auxiliary turbines maximum power usually did not exceed 5-6 MW) [8, 9]. Auxiliary low-power steam turbines in such marine systems (turbo-generators for the electricity generator drive or steam turbines for water pumps drive) are simple steam turbines without steam extractions [10]. 
Several steam turbine producers in their catalogues offer lowpower steam turbines for marine applications which have at least one steam extraction in order to ensure simultaneous power and heat production [11]. One of such low-power steam turbine, which has one steam extraction and is made for the usage in the marine applications, is analyzed in this paper. Thermodynamic (energy and exergy) analysis of steam turbine is performed, based on operating parameters provided by the producer.

Analyzed low-power steam turbine is divided in two parts - High Pressure (HP) part before steam extraction and Low Pressure (LP) part after steam extraction. Thermodynamic analysis is performed for each turbine part independently as well as for the whole turbine. Mechanical losses of each turbine part as well as of the whole turbine are included in the analysis. It is concluded that LP part produces less power in comparison with HP part, but has notable higher efficiencies and lower losses (from both the energy and exergy point of view). Energy and exergy flow streams throughout each turbine part and the whole turbine are also presented and discussed.

\section{DESCRIPTION AND OPERATING CHARACTERISTICS OF THE ANALYZED LOW-POWER STEAM TURBINE WITH ONE EXTRACTION / Opis i radne značajke analizirane parne turbine male snage sjednim oduzimanjem pare}

Analyzed low-power steam turbine consists of two parts - the first is High Pressure (HP) part between steam entrance into the turbine and steam extraction, while Low Pressure (LP) part can be seen between steam extraction and steam outlet from the turbine (condenser inlet), Fig. 1. Steam produced in steam generator [12] expanded firstly in HP part of the turbine, after which follows steam extraction. Extracted steam can be led to any marine heat consumer. Remaining steam mass flow rate expanded through LP part of the turbine and after expansion is led to the main marine steam condenser, which is usually shell and tube type heat exchanger [13].

Steam turbine analyzed in this paper and presented in Fig. 1 drives electricity generator with the necessary usage of gearbox which reduces turbine revolutions and ensures proper drive of any power consumer (not necessary electricity generator only). Thermodynamic analysis of this steam turbine is based on steam expansion processes - real (polytropic) expansion process whose description requires turbine operating points presented in Fig. 1 and ideal (isentropic) steam expansion process whose description requires assumption of constant steam specific entropy during the expansion process [14].

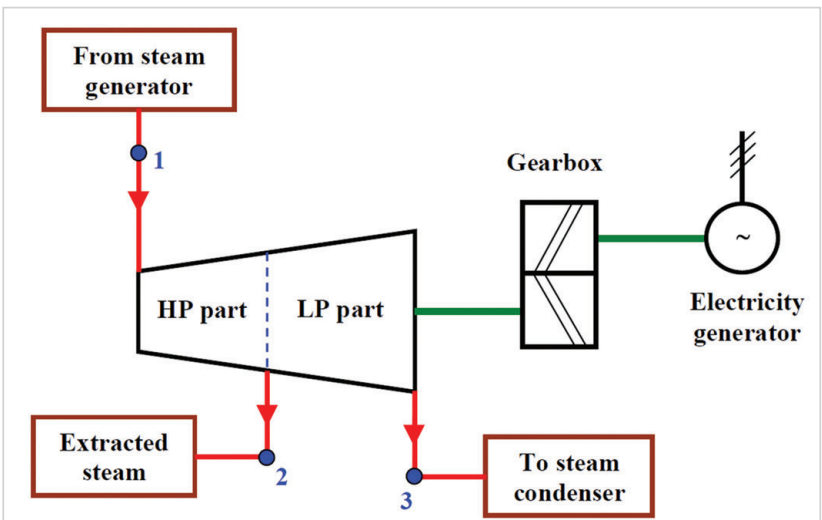

Figure 1 General scheme of the analyzed low-power steam turbine with marked operating points

Slika 1. Opća shema analizirane parne turbine male snages označenim radnim točkama

As analysis in this paper is performed not only for the entire steam turbine, but also for each turbine part, energy analysis requires comparison of real (polytropic) and ideal (isentropic) steam expansion processes for each turbine part. Expansion processes (ideal and real) of each analyzed steam turbine part begin at the same steam pressure and finished at the same steam pressure. Therefore, for the HP part of the analyzed turbine the ideal steam expansion process (points 1-2is, Fig. 2) is compared with real steam expansion process (points 1-2, Fig. 2), while for the LP part of the analyzed turbine the ideal steam expansion process (points 2-3is, Fig. 2) is compared with real steam expansion process (points 2-3, Fig. 2) in order to be able to perform complete energy analysis of the entire turbine and both of its parts.

Exergy analysis of presented steam turbine (or any other steam turbine [15]) is based on real (polytropic) steam expansion process (points 1-2-3 in Fig. 2), which is also valid in exergy analysis of each turbine part.

From Fig. 2 can be observed that the majority of real steam expansion process through the analyzed turbine is in the superheated steam area, while only the last section of LP turbine part falls under the steam saturation line.

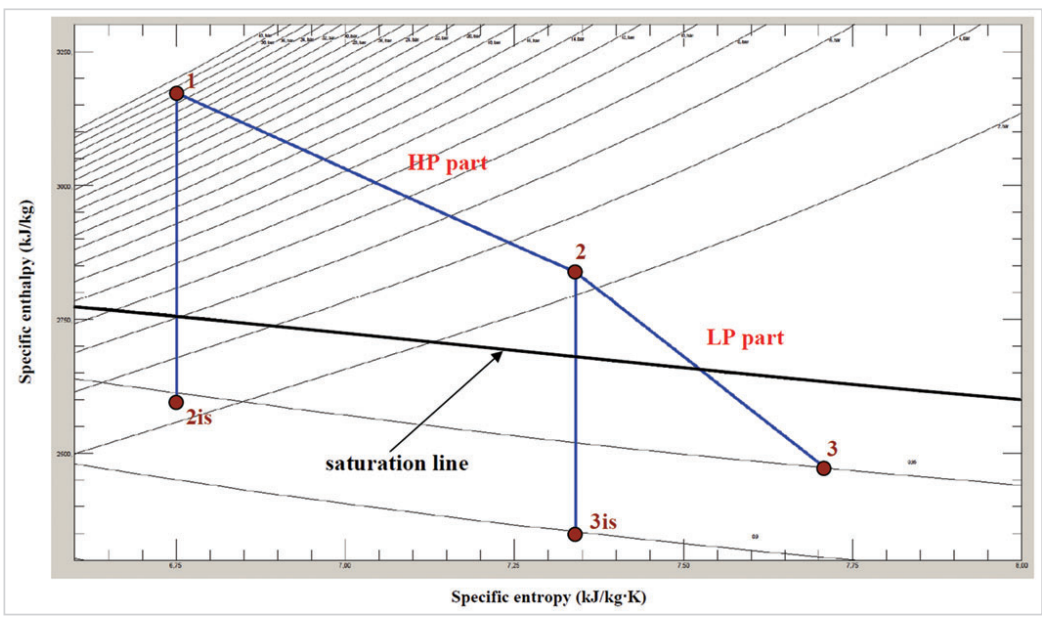

Figure 2 Ideal (isentropic) and real (polytropic) steam expansion through the analyzed turbine presented in h-s diagram - plotted from [16] Slika 2. Idealna (izentropna) istvarna (politropska) ekspanzija pare kroz analizanu turbinu prikazanu u h-s dijagramu - nacrtanom iz [16] 


\section{STEAM TURBINE THERMODYNAMIC ANALYSIS / Termodinamička analiza parne turbine}

3.1. General equations for the thermodynamic analysis of any control volume or system / Opće jednadžbe za termodinamičku analizu bilo kojeg kontrolnog volumena ili sustava

Thermodynamic analysis (energy and exergy analysis) of any control volume or system is based on the first and the second law of thermodynamics. The first law of thermodynamics defines energy analysis [17], which is independent of the environment in which analyzed control volume or a system operates [18]. On the other side, exergy analysis of any control volume or system is based on the second law of thermodynamics [19] and it takes into account the parameters of the ambient in which control volume or a system operates [20].

Mass flow rate balance for any control volume or system in steady state, when the mass flow rate leakage did not occur, is [21]:

$$
\sum \dot{m}_{\text {in }}=\sum \dot{m}_{\text {out }}
$$

Disregarding potential and kinetic energy, the energy balance of a control volume or system can be defined, according to $[22,23]$, by using the following equation:

$$
\sum \dot{m}_{\text {in }} \cdot h_{\text {in }}-\sum \dot{m}_{\text {out }} \cdot h_{\text {out }}+\dot{Q}-P=0 \text {. }
$$

Any fluid flow has a certain amount of energy which can be defined as $[24,25]$ :

$$
\dot{E}_{\text {en }}=\dot{m} \cdot h \text {. }
$$

The overall definition of any control volume or system energy efficiency, according to $[26,27]$ is:

$$
\eta_{\mathrm{en}}=\frac{\text { Energy output }(\text { Energy outlet })}{\text { Energy input }(\text { Energy inlet) }}
$$

Disregarding potential and kinetic energy, the exergy balance of a control volume or system can be defined, according to $[28,29]$, by using the following equation:

$$
\sum \dot{m}_{\text {in }} \cdot \varepsilon_{\text {in }}-\sum \dot{m}_{\text {out }} \cdot \varepsilon_{\text {out }}+\dot{X}_{\text {heat }}-P-\dot{E}_{\text {ex,loss }}=0
$$

In the Eq. $5, \varepsilon$ is specific exergy, which is defined as [30, 31]:

$$
\varepsilon=\left(h-h_{0}\right)-T_{0} \cdot\left(s-s_{0}\right)
$$

while $\dot{X}_{\text {heat }}$ is the net exergy transfer by heat (at temperature $T$ ), which is defined, according to $[32,33]$, as:

$$
\dot{X}_{\text {heat }}=\sum\left(1-\frac{T_{0}}{T}\right) \cdot \dot{Q}
$$

Amount of exergy for any fluid flow can be defined according to $[34,35]$ as follows :

$$
\dot{E}_{\mathrm{ex}}=\dot{m} \cdot \varepsilon=\dot{m} \cdot\left[\left(h-h_{0}\right)-T_{0} \cdot\left(s-s_{0}\right)\right] .
$$

The overall definition of any control volume or system exergy efficiency, according to $[36,37]$ is:

$$
\eta_{\mathrm{ex}}=\frac{\text { Exergy output }(\text { Exergy outlet })}{\text { Exergy input }(\text { Exergy inlet })} \text {. }
$$

\subsection{Analysis of low-power steam turbine with one extraction for marine applications / Analiza parne turbine male snage s jednim oduzimanjem za primjenu $u$ pomorstvu}

Thermodynamic (energy and exergy) analysis of low-power steam turbine with one extraction for marine applications (along with the analysis of each turbine part) is performed by using turbine operating points presented in Fig. 1 and Fig. 2. The mechanical efficiency of the whole turbine and both of its parts is assumed to be $95 \%$ (according to data from $[38,39]$ ).

3.2.1. Low-power steam turbine with one extraction energy analysis / Energijska analiza parne turbine male snage s jednim oduzimanjem

Real (polytropic) developed power of each turbine part and the whole turbine is:

- HP part:

$$
\begin{aligned}
& P_{\text {re,HP }}=\dot{m}_{1} \cdot\left(h_{1}-h_{2}\right) \cdot \eta_{\text {mech }} . \\
& \text { LP part: } \\
& P_{\text {re,LP }}=\left(\dot{m}_{1}-\dot{m}_{2}\right) \cdot\left(h_{2}-h_{3}\right) \cdot \eta_{\text {mech }} .
\end{aligned}
$$

- LP part:

- Whole turbine:

$P_{\mathrm{re}, \mathrm{WT}}=P_{\mathrm{re}, \mathrm{HP}}+P_{\mathrm{re}, \mathrm{LP}}=\left[\dot{m}_{1} \cdot\left(h_{1}-h_{2}\right)+\left(\dot{m}_{1}-\dot{m}_{2}\right) \cdot\left(h_{2}-h_{3}\right)\right] \cdot \eta_{\text {mech }}(12)$

Mechanical losses of each turbine part and the whole turbine are calculated in accordance with real (polytropic) developed power:

- HP part:

$\dot{E}_{\text {mech,loss }, \mathrm{HP}}=\dot{m}_{1} \cdot\left(h_{1}-h_{2}\right) \cdot\left(1-\eta_{\text {mech }}\right)$

- LP part:

$\dot{E}_{\text {mech,loss,LP }}=\left(\dot{m}_{1}-\dot{m}_{2}\right) \cdot\left(h_{2}-h_{3}\right) \cdot\left(1-\eta_{\text {mech }}\right)$.

Whole turbine:

$\dot{E}_{\text {mech,loss, WT }}=\left[\dot{m}_{1} \cdot\left(h_{1}-h_{2}\right)+\left(\dot{m}_{1}-\dot{m}_{2}\right) \cdot\left(h_{2}-h_{3}\right)\right] \cdot\left(1-\eta_{\text {mech }}\right) .(15)$ Ideal (isentropic) power of each turbine part and the whole turbine is:

- HP part:

$P_{\text {is, HP }}=\dot{m}_{1} \cdot\left(h_{1}-h_{2 \text { is }}\right) \cdot \eta_{\text {mech }}$

- LP part:

$P_{\text {is,LP }}=\left(\dot{m}_{1}-\dot{m}_{2}\right) \cdot\left(h_{2}-h_{3 \text { is }}\right) \cdot \eta_{\text {mech }}$

Whole turbine:

$P_{\text {is, WT }}=P_{\text {is, HP }}+P_{\text {is,LP }}=\left[\dot{m}_{1} \cdot\left(h_{1}-h_{2 \text { is }}\right)+\left(\dot{m}_{1}-\dot{m}_{2}\right) \cdot\left(h_{2}-h_{3 \text { is }}\right)\right] \cdot \eta_{\text {mech }} \cdot(18)$

Energy losses of each turbine part and the whole turbine are calculated as a difference between the ideal (isentropic) and real (polytropic) power:

- HP part:

$\dot{E}_{\text {en }, \mathrm{loss}, \mathrm{HP}}=P_{\mathrm{is}, \mathrm{HP}}-P_{\mathrm{re}, \mathrm{HP}}=\left[\dot{m}_{1} \cdot\left(h_{1}-h_{2 \text { is }}\right)-\dot{m}_{1} \cdot\left(h_{1}-h_{2}\right)\right] \cdot \eta_{\text {mech }}$

- LP part:

$\dot{E}_{\mathrm{en}, \mathrm{loss}, \mathrm{LP}}=P_{\mathrm{is}, \mathrm{LP}}-P_{\mathrm{re}, \mathrm{LP}}=\left[\left(\dot{m}_{1}-\dot{m}_{2}\right) \cdot\left(h_{2}-h_{3 \mathrm{is}}\right)-\left(\dot{m}_{1}-\dot{m}_{2}\right) \cdot\left(h_{2}-h_{3}\right)\right] \cdot \eta_{\text {mech }}(20)$ Whole turbine:

$\dot{E}_{\text {en,loss, WT }}=P_{\text {is, WT }}-P_{\text {re,WT }}=\dot{E}_{\text {en,loss, } \mathrm{HP}}+\dot{E}_{\text {en,loss,LP }}$

Energy efficiencies of each turbine part and the whole turbine are calculated as a ratio between real (polytropic) and ideal (isentropic) power:

- HP part:

$\eta_{\mathrm{en}, \mathrm{HP}}=\frac{P_{\mathrm{re}, \mathrm{HP}}}{P_{\mathrm{is}, \mathrm{HP}}}=\frac{\dot{m}_{1} \cdot\left(h_{1}-h_{2}\right) \cdot \eta_{\text {mech }}}{\dot{m}_{1} \cdot\left(h_{1}-h_{2 \mathrm{is}}\right) \cdot \eta_{\text {mech }}}=\frac{\left(h_{1}-h_{2}\right)}{\left(h_{1}-h_{2 \mathrm{is}}\right)}$.

$$
\begin{aligned}
& \text { LP part: } \\
& \eta_{\mathrm{en}, \mathrm{LP}}=\frac{P_{\mathrm{re}, \mathrm{LP}}}{P_{\text {is }, \mathrm{LP}}}=\frac{\left(\dot{m}_{1}-\dot{m}_{2}\right) \cdot\left(h_{2}-h_{3}\right) \cdot \eta_{\text {mech }}}{\left(\dot{m}_{1}-\dot{m}_{2}\right) \cdot\left(h_{2}-h_{3 \text { is }}\right) \cdot \eta_{\text {mech }}}=\frac{\left(h_{2}-h_{3}\right)}{\left(h_{2}-h_{3 \mathrm{is}}\right)} .
\end{aligned}
$$

Whole turbine:

$\eta_{\mathrm{en}, \mathrm{WT}}=\frac{P_{\mathrm{re}, \mathrm{WT}}}{P_{\mathrm{is}, \mathrm{WT}}}=\frac{P_{\mathrm{re}, \mathrm{HP}}+P_{\mathrm{re}, \mathrm{LP}}}{P_{\mathrm{is}, \mathrm{HP}}+P_{\mathrm{is}, \mathrm{LP}}}$

Specific energy losses of each turbine part and the whole turbine are calculated as a ratio between energy loss and real (polytropic) power:

HP part:

$\dot{E}_{\text {en }, \text { specific }, \mathrm{HP}}=\frac{\dot{E}_{\text {en }, \text { loss }, \mathrm{HP}}}{P_{\mathrm{re}, \mathrm{HP}}}=\frac{P_{\mathrm{is}, \mathrm{HP}}-P_{\mathrm{re}, \mathrm{HP}}}{P_{\mathrm{re}, \mathrm{HP}}}=\frac{P_{\mathrm{is}, \mathrm{HP}}}{P_{\mathrm{re}, \mathrm{HP}}}-1$. 
- LP part:

$\dot{E}_{\text {en }, \text { specific }, \mathrm{LP}}=\frac{\dot{E}_{\mathrm{en}, \mathrm{loss}, \mathrm{LP}}}{P_{\mathrm{re}, \mathrm{LP}}}=\frac{P_{\mathrm{is}, \mathrm{LP}}-P_{\mathrm{re}, \mathrm{LP}}}{P_{\mathrm{re}, \mathrm{LP}}}=\frac{P_{\mathrm{is}, \mathrm{LP}}}{P_{\mathrm{re}, \mathrm{LP}}}-1$

- Whole turbine:

$\dot{E}_{\text {en,specific, } \mathrm{WT}}=\frac{\dot{E}_{\text {en,loss, WT }}}{P_{\text {re,WT }}}=\frac{P_{\text {is, } \mathrm{WT}}-P_{\text {re, } \mathrm{WT}}}{P_{\mathrm{re}, \mathrm{WT}}}=\frac{P_{\mathrm{is}, \mathrm{WT}}}{P_{\mathrm{re}, \mathrm{WT}}}-1$.

3.2.2. Low-power steam turbine with one extraction exergy analysis / Eksergijska analiza parne turbine male snage $s$ jednim oduzimanjem

Exergy losses (exergy destructions) of each turbine part and the whole turbine are calculated as:

- HP part:

$\dot{E}_{\text {ex }, \text { loss }, \mathrm{HP}}=\dot{m}_{1} \cdot \varepsilon_{1}-\dot{m}_{1} \cdot \varepsilon_{2}-P_{\mathrm{re}, \mathrm{HP}}$

- LP part:

$\dot{E}_{\text {ex }, \mathrm{loss}, \mathrm{LP}}=\left(\dot{m}_{1}-\dot{m}_{2}\right) \cdot \varepsilon_{2}-\left(\dot{m}_{1}-\dot{m}_{2}\right) \cdot \varepsilon_{3}-P_{\mathrm{re}, \mathrm{LP}}=$

$=\dot{m}_{3} \cdot \varepsilon_{2}-\dot{m}_{3} \cdot \varepsilon_{3}-P_{\mathrm{re}, \mathrm{LP}}$.

- Whole turbine:

$\dot{E}_{\text {ex,loss, WT }}=\dot{m}_{1} \cdot \varepsilon_{1}-\dot{m}_{2} \cdot \varepsilon_{2}-\dot{m}_{3} \cdot \varepsilon_{3}-P_{\text {re, WT }}$

Exergy efficiencies of each turbine part and the whole turbine are:

- HP part:

$$
\begin{aligned}
& \eta_{\mathrm{ex}, \mathrm{HP}}=\frac{P_{\mathrm{re}, \mathrm{HP}}}{\dot{m}_{1} \cdot \varepsilon_{1}-\dot{m}_{1} \cdot \varepsilon_{2}} . \\
& \text { LP part: } \\
& \eta_{\mathrm{ex}, \mathrm{LP}}=\frac{P_{\mathrm{re}, \mathrm{LP}}}{\left(\dot{m}_{1}-\dot{m}_{2}\right) \cdot \varepsilon_{2}-\left(\dot{m}_{1}-\dot{m}_{2}\right) \cdot \varepsilon_{3}}=\frac{P_{\mathrm{re}, \mathrm{LP}}}{\dot{m}_{3} \cdot \varepsilon_{2}-\dot{m}_{3} \cdot \varepsilon_{3}} .
\end{aligned}
$$

- Whole turbine:

$$
\eta_{\mathrm{ex}, \mathrm{WT}}=\frac{P_{\mathrm{re}, \mathrm{WT}}}{\dot{m}_{1} \cdot \varepsilon_{1}-\dot{m}_{2} \cdot \varepsilon_{2}-\dot{m}_{3} \cdot \varepsilon_{3}} \text {. }
$$

Specific exergy losses (specific exergy destructions) of each turbine part and the whole turbine are calculated as:

- HP part

$\dot{E}_{\text {ex,specific, HP }}=\frac{\dot{E}_{\text {ex,loss, HP }}}{P_{\text {re }, \mathrm{HP}}}$

- LP part:

$\dot{E}_{\text {ex,specific }, \mathrm{LP}}=\frac{\dot{E}_{\text {ex,loss,LP}}}{P_{\text {re }, \mathrm{LP}}}$

- Whole turbine:

$\dot{E}_{\text {ex,specific, WT }}=\frac{\dot{E}_{\text {ex,loss,WT }}}{P_{\text {re, } \mathrm{WT}}}$.

\section{OPERATING PARAMETERS OF LOW-POWER STEAM TURBINE WITH ONE EXTRACTION / Radni parametri parne turbine male snage s jednim oduzimanjem}

Thermodynamic (energy and exergy) analysis requires knowledge of steam operating parameters (temperature, pressure and mass flow rate) at each turbine operating point presented in Fig. 1. Those operating parameters are found in the analyzed steam turbine producer catalogue and presented in Table 1. Steam specific enthalpy, specific entropy and specific exergy at the same turbine operating points were calculated by using NIST-REFPROP 9.0 software [16].

It should be noted that steam specific enthalpy after ideal (isentropic) expansion in HP turbine part (operating point 2is, Fig. 2) is calculated also with NIST-REFPROP 9.0 software [16] by using steam pressure at the HP turbine part outlet and the same steam specific entropy as at the HP turbine part inlet (operating point 1, Fig. 2). The identical procedure is used for calculation of steam specific enthalpy after ideal (isentropic) expansion in LP turbine part. The same calculation procedure can be found in the literature, applied during the energy analyses of other steam turbines $[40,41]$.

Specific exergies in each turbine operating point (presented in Table 1) are calculated for the base ambient state (the base ambient conditions) which is in this paper taken as proposed in [42]:

$$
\begin{aligned}
& \text { - pressure: } \quad p_{0}=100 \mathrm{kPa}=1 \mathrm{bar} \text {, } \\
& \text { - temperature: } T_{0}=298 \mathrm{~K}=25^{\circ} \mathrm{C} \text {. }
\end{aligned}
$$

Steam turbine producer for defined operating parameters in Table 1 specifies an electricity generator driving power of $1100 \mathrm{~kW}$. This power also includes losses in the gearbox and in electricity generator, Fig. 1. Therefore, produced power at the turbine outlet shaft should be higher than the specified value for mentioned losses.

\section{THE RESULTS OF LOW-POWER STEAM TURBINE WITH ONE EXTRACTION ANALYSIS AND DISCUSSION / Rezultati analize i rasprava o parnoj turbini male snage s jednim oduzimanjem}

5.1. The results of energy analysis / Rezultati energijske analize

The results of low-power steam turbine energy analysis showed that the majority of real (polytropic) turbine power is produced in HP turbine part (66.10\%) while LP turbine part produces 


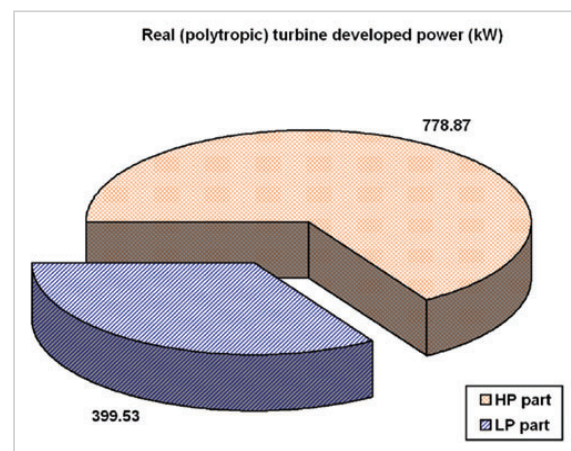

(a)

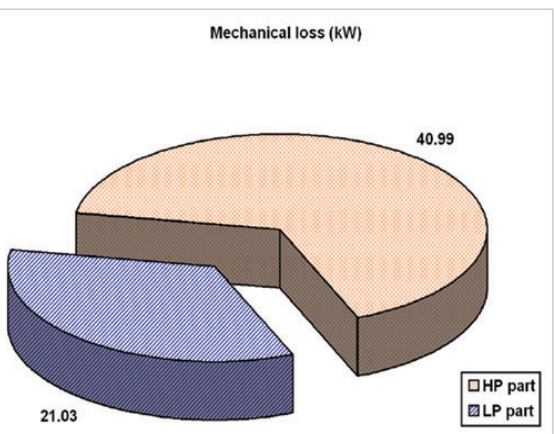

(b)

Figure 3 Analyzed turbine: (a) Real (polytropic) developed power; (b) Mechanical loss Slika 3. Analizirana turbina: (a) Stvarna (politropska) razvijena snaga; (b) Mehanički gubitak

only $33.90 \%$ of real cumulative power, Fig. 3 (a). For the steam operating parameters specified by turbine producer and presented in Table 1, cumulative real (polytropic) developed power at the turbine shaft outlet is equal to $1178.40 \mathrm{~kW}$. This turbine power is calculated by using Eq. 12, which takes into account mechanical losses in both turbine parts.

The accuracy of calculated real developed power at the turbine shaft outlet (1178.40 kW), along with used assumption for mechanical losses inside both turbine parts, can be easily validated. If this power is reduced for losses in the gearbox (according to [38] gearbox efficiency can be taken between 95\% and $96 \%$ ) and for losses in the electricity generator (according to [39] electricity generator efficiency is around 98\%), Fig. 1, electricity generator driving power will be around $1100 \mathrm{~kW}$, as specified by turbine producer.

Identical to turbine real developed power, the majority of turbine mechanical losses appears in HP turbine part (Fig. 3 (b)), while the mechanical losses of the whole turbine are equal to $62.02 \mathrm{~kW}$.

Ideal (isentropic) power of the whole analyzed steam turbine is calculated by using Eq. 18 and is equal to 1875.14
$\mathrm{kW}$. The majority of ideal power of the whole turbine $(71.75 \%)$ refers to the HP turbine part, while only $28.25 \%$ refers to the LP turbine part, Fig. 4 (a).

Energy losses of each turbine part and whole turbine are calculated by using Eq. 19 - Eq. 21 and presented in Fig. 4 (b). Energy loss of the whole turbine is equal to $696.74 \mathrm{~kW}$ and the highest amount of that loss (81.33\%) refers to the HP turbine part. It is interesting to observe this fact, because LP turbine part operates in much heavier conditions when compared to HP part (last stages of LP turbine part operates with wet steam which, due to water droplets, increases inner losses). However, $\mathrm{HP}$ turbine part has much higher energy loss (in comparison to LP part) due to significantly higher steam mass flow rate.

Energy losses of steam turbines or its parts are reverse proportional to turbine (or its parts) energy efficiencies [10]. The same conclusion can be obtained when compared Fig. 4 (b) and Fig. 5. LP part of the analyzed steam turbine has an energy efficiency of $75.43 \%$ - much higher in comparison to the HP turbine part which energy efficiency equals $57.89 \%$. The energy efficiency of the whole turbine is $62.84 \%$, what is expected for low-power steam turbines $[43,44]$.

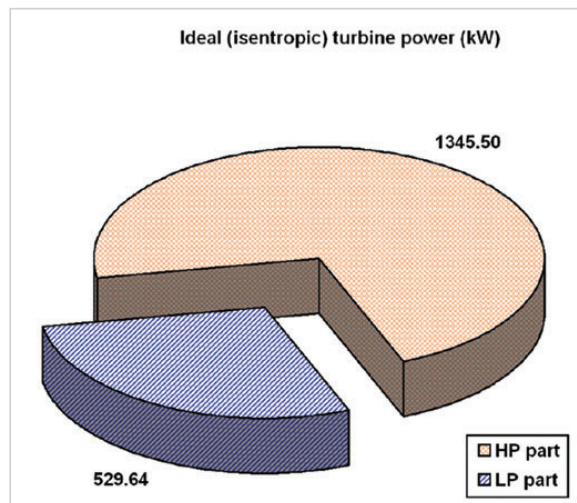

(a)

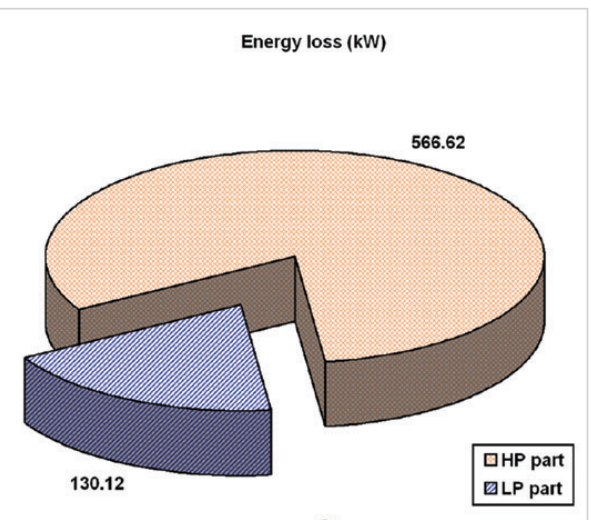

(b)

Figure 4 Analyzed turbine: (a) Ideal (isentropic) power; (b) Energy loss Slika 4. Analizirana turbina: (a) Idealna (izentropska) snaga; (b) Gubitak energije 
Specific energy loss of the steam turbine or any of its parts is defined by using the same methodology as for specific fuel consumption, which is commonly used parameter for tracking the internal combustion engine process [45]. Specific energy loss of steam turbine or each turbine part is obtained by dividing of energy loss with real developed power (for the whole turbine as well as for each turbine part, Eq. 25 - Eq. 27). Specific energy loss presents which part in the real developed power takes an energy loss (for the whole turbine or each of it parts). From Fig. 5 can be seen that specific energy loss of HP turbine part has a share of $72.75 \%$ in real developed power of this turbine part. The same parameter for the LP turbine part is equal to $32.57 \%$ and for the whole turbine is equal to $59.13 \%$.

Regardless of worse operating conditions (wet steam, high steam volume and speed), from Fig. 5 it can be seen that LP part of the analyzed turbine has much higher energy efficiency and much lower specific energy loss in comparison with the HP turbine part.

Energy flow streams of the analyzed steam turbine (turbine real developed power and steam flow streams), presented in Fig. 6 are calculated by using general equations (Eq. 1 - Eq. 4) and Eq. 10 - Eq. 27 as well as steam operating parameters from Table 1. It should be noted that analyzed turbine parts (HP part and LP part) are separated in Fig. 6 in order to present energy flow streams of each turbine part and of the whole turbine.

Real (polytropic) produced power of the whole turbine (of the both turbine parts) is $1240.42 \mathrm{~kW}$ and it is reduced for mechanical losses of both turbine parts (62.02 kW), therefore power which can be used for power consumer drive (power at the turbine shaft outlet) is equal to 1178.40 kW, Fig. 6 .

While presenting energy flow streams of the analyzed steam turbine (or any other steam turbine), energy balance equation (Eq. 2) considered only mechanical losses of each turbine part (and cumulative mechanical losses of the whole turbine) as the real steam turbine energy dissipation parameters.

In comparison with energy analysis, exergy analysis of the same steam turbine will take into account additional losses of steam (along with mechanical losses). Such steam losses (steam exergy destruction) are caused by taking into account parameters of the ambient (pressure and temperature) in which analyzed turbine operates. The energy analysis did not take into account the parameters of the ambient; therefore additional steam energy losses did not occur [46].

It should be noted that, due to the lack of data, steam mass flow rates lost on the front and rear gland seals of the analyzed turbine are not taken into account in this analysis. It can be assumed that the cumulative mass flow rate lost on both turbine gland seals (front and rear) is approximately equal to $1 \%$ of the steam mass flow rate which enters in the analyzed turbine $[47,48]$.

\subsection{The results of exergy analysis / Rezultati eksergijske analize}

Exergy losses (exergy destructions) of the whole turbine and each turbine part are calculated by using Eq. 28 - Eq. 30. Similar

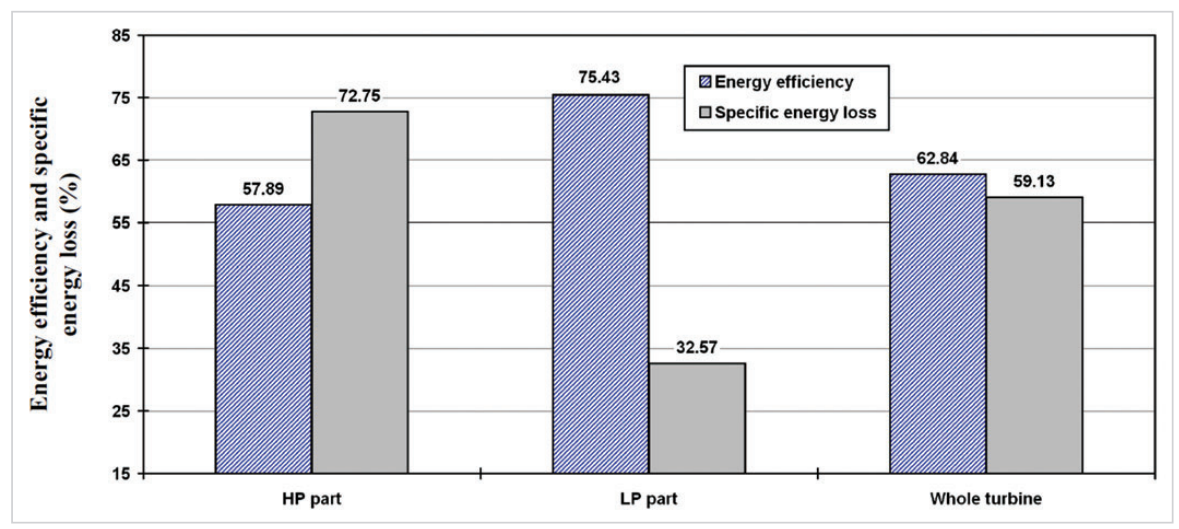

Figure 5 Energy efficiency and specific energy loss of the analyzed steam turbine and its parts Slika 5. Energetska učinkovitost i specifični gubitak energije analizirane parne turbine i njezinih dijelova

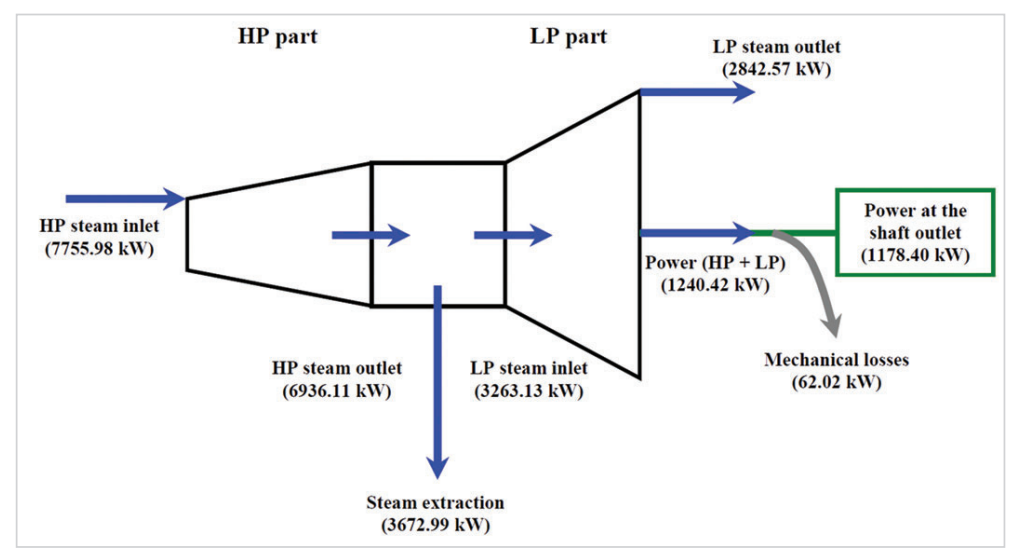

Figure 6 Energy flow streams (steam and power) throughout the analyzed steam turbine Slika 6. Struje protoka energije (para i snaga) kroz analiziranu parnu turbinu 
to energy losses, exergy loss of HP turbine part takes a share of $76.15 \%$ in cumulative exergy loss of the whole turbine. Therefore, LP turbine part share in the cumulative exergy loss of the whole turbine is only $23.85 \%$, Fig. 7. As can be seen from Fig. 7, cumulative exergy loss (cumulative exergy destruction) of the whole turbine is equal to $618.50 \mathrm{~kW}$, and it consists of steam exergy destruction and mechanical losses of both turbine parts (HP and LP part).

Cumulative exergy destruction (kW)

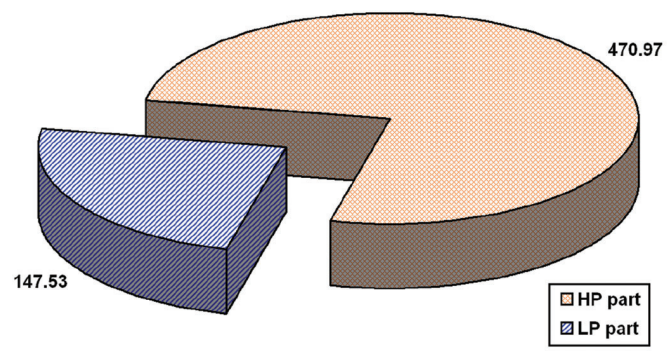

Figure 7 Cumulative exergy destruction of the analyzed steam turbine Slika 7. Kumulativni eksergijski gubitak analizirane parne turbine

The exergy efficiency of the analyzed steam turbine and both of its parts have the same trend as energy efficiency - Fig. 5 and Fig. 8. LP turbine part has significantly higher exergy efficiency (73.03\%) in comparison with the HP turbine part (62.32\%), while the whole turbine exergy efficiency is equal to $65.58 \%$, Fig. 8. LP turbine part has lower exergy than energy efficiency, while the exergy efficiencies of HP turbine part and the whole turbine are higher in comparison with energy efficiencies, Fig. 5 and Fig. 8.

Specific exergy destruction (specific exergy loss) of the whole turbine and each turbine part is calculated by using Eq. 34 - Eq. 36 and is obtained by dividing of exergy loss (exergy destruction) with real developed power. Specific exergy destruction of HP turbine part is much higher in comparison with the LP turbine part $(60.47 \%$ vs. $36.93 \%)$, while the whole turbine has specific exergy destruction equal to $52.49 \%$, Fig. 8 . LP turbine part has higher exergy than energy specific loss, while HP turbine part and the whole turbine have much lower specific exergy losses when compared to specific energy losses, Fig. 5 and Fig. 8.

Exergy flow streams of steam and power throughout the analyzed turbine, according to operating parameters from Table 1 as well as by using general equations (Eq. 5 - Eq. 9) and Eq. 28 Eq. 36 are presented in Fig. 9. Taking into account the parameters of the ambient (pressure and temperature) generates additional steam exergy loss (when compared to energy flow streams) which for the whole turbine is $556.48 \mathrm{~kW}$. In the cumulative exergy destruction of the whole turbine are included mentioned steam exergy loss (steam exergy destruction) and mechanical losses.

The influence of the ambient temperature change on steam turbine exergy efficiencies and exergy losses is usually low [49, 50]. Still, it can be concluded that an increase in the ambient temperature reduces turbine exergy efficiency and increases turbine exergy destruction [8]. For the same mechanical efficiency of each turbine part and the whole turbine, mechanical losses will remain the same as presented in Fig. 3 (b) and in Fig. 9, regardless of the ambient temperature.

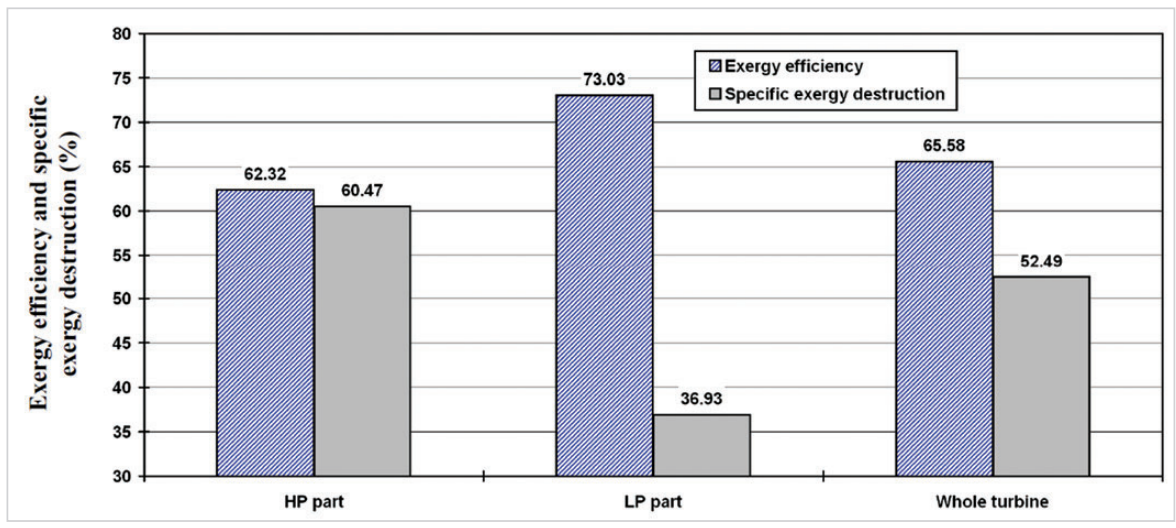

Figure 8 Exergy efficiency and specific exergy loss of the analyzed steam turbine and its parts Slika 8. Učinkovitost i specifični gubitak eksergije analizirane parne turbine i njezinih dijelova

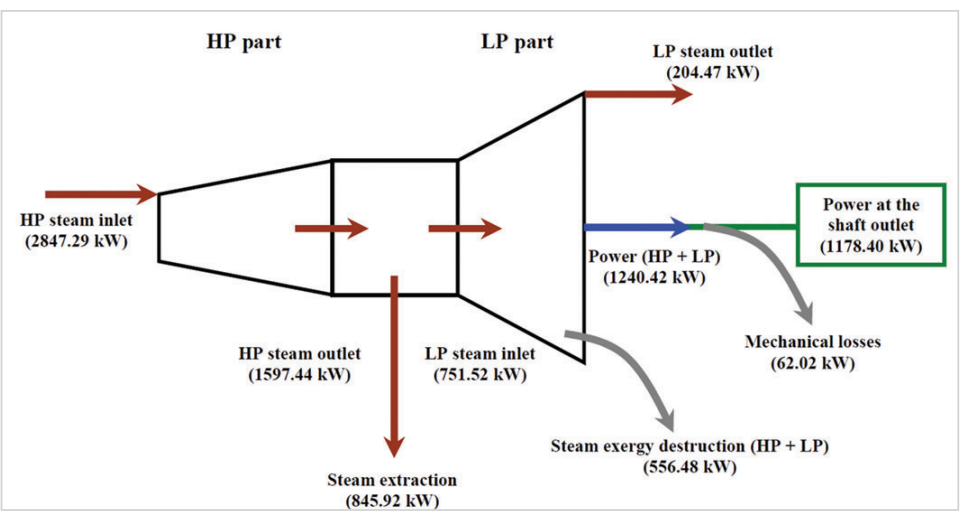

Figure 9 Exergy flow streams (steam and power) throughout the analyzed steam turbine Slika 9. Struje protoka eksergije (para i snaga) kroz analiziranu parnu turbinu 


\section{CONCLUSIONS / Zaključci}

This paper focuses on the thermodynamic (energy and exergy) analysis of low-power steam turbine with one extraction for marine applications. According to the producer data, losses and efficiencies of the whole turbine and both turbine parts (HP and LP part) are calculated. Energy and exergy flow streams are also presented throughout the analyzed turbine along with mechanical losses as an integral part of the analysis.

The major conclusions obtained from the presented analysis are: HP turbine part, in comparison with the LP turbine part, produces higher power (ideal and real), but also has higher mechanical, energy and exergy losses.

- Regardless of the fact that LP turbine part operates in much heavier conditions in comparison with the HP turbine part (with wet steam, which has a high volume flow), LP turbine part has significantly higher energy and exergy efficiencies and lower specific energy and exergy losses (destructions).

- In the turbine energy analysis, the only losses are mechanical losses (if the steam which passes through front and rear turbine gland seal is neglected). In the turbine exergy analysis additional loss occurs (steam exergy destruction).

- The whole observed turbine has energy and exergy efficiencies equal to $62.84 \%$ and $65.58 \%$, while energy and exergy turbine losses are $696.74 \mathrm{~kW}$ and $618.50 \mathrm{~kW}$, what are expected efficiencies and losses for low-power steam turbine.

- Analyzed turbine at the shaft outlet produces real power equal to $1178.40 \mathrm{~kW}$, which can be used for any power consumer drive.

- Presented steam turbine, along with produced power, delivered a notable amount of heat (by steam extraction) to any heat consumer or more of them.

\section{Acknowledgment / Zahvala}

This research has been supported by the Croatian Science Foundation under the project IP-2018-01-3739, CEEPUS network CIII-HR-0108, European Regional Development Fund under the grant KK.01.1.1.01.0009 (DATACROSS), University of Rijeka scientific grant uniri-tehnic-18-275-1447 and University of Rijeka scientific grant uniri-tehnic-18-18-1146.

\section{Nazivlje}

Abbreviations:

$\begin{array}{ll}\text { HP } & \text { High Pressure } \\ \text { LNG } & \text { Liquefied Natural Gas } \\ \text { LP } & \text { Low Pressure } \\ \text { WT } & \text { Whole Turbine }\end{array}$

Latin Symbols:

$\dot{E} \quad$ the total energy/exergy of a flow, kW

$h$ specific enthalpy, $\mathrm{kJ} / \mathrm{kg}$

$\dot{m} \quad$ mass flow rate, $\mathrm{t} / \mathrm{h}$ or $\mathrm{kg} / \mathrm{s}$

$p \quad$ pressure, bar or $\mathrm{kPa}$

$P \quad$ power, $\mathrm{kW}$

$\dot{Q} \quad$ energy heat transfer, kW

$S \quad$ specific entropy, $\mathrm{kJ} / \mathrm{kg} \cdot \mathrm{K}$

$T \quad$ temperature, $\mathrm{K}$ or ${ }^{\circ} \mathrm{C}$

$\dot{X}_{\text {heat }}$ exergy heat transfer, kW
Greek symbols: / Grčki simboli

$\varepsilon \quad$ specific exergy, $\mathrm{kJ} / \mathrm{kg}$

$\eta \quad$ efficiency, $\%$

Subscripts:

0 the ambient state

en energy

ex exergy

in inlet (input)

is isentropic (ideal expansion)

mech mechanical

out outlet (output)

re real (polytropic expansion)

\section{REFERENCES / Literatura}

[1] Zhao, Z., Su, S., Si, N., Hu, S., Wang, Y., Xu, J., Jiang, L., Chen, G., Xiang, J.: Exergy analysis of the turbine system in a $1000 \mathrm{MW}$ double reheat ultra-supercritical power plant, Energy 119, p. 540-548, 2017. https://doi.org/10.1016/j. energy.2016.12.072

[2] Naserbegi, A., Aghaie, M., Minuchehr, A., Alahyarizadeh, Gh.: A novel exergy optimization of Bushehr nuclear power plant by gravitational search algorithm (GSA), Energy 148, p. 373-385, 2018.https://doi.org/10.1016/j. energy.2018.01.119

[3] Amiralipour, M., Kouhikamali, R.: Potential analysis and technical-economic optimization of conversion of steam power plant into combined water and power, Applied Thermal Engineering 151, p. 191-198, 2019. https://doi. org/10.1016/j.applthermaleng.2019.02.005

[4] Lorencin, I., Anđelić, N., Mrzljak, V., Car, Z.: Genetic Algorithm Approach to Design of Multi-Layer Perceptron for Combined Cycle Power Plant Electrical Power Output Estimation, Energies 12 (22), 4352, 2019. https://doi. org/10.3390/en 12224352

[5] Adibhatla, S., Kaushik, S. C.: Energy, exergy, economic and environmental (4E) analyses of a conceptual solar aided coal fired $500 \mathrm{MWe}$ thermal power plant with thermal energy storage option, Sustainable Energy Technologies and Assessments 21, p. 89-99, 2017. https://doi.org/10.1016/j.seta.2017.05.002

[6] Mrzljak, V., Poljak, I.: Energy Analysis of Main Propulsion Steam Turbine from Conventional LNG Carrier at Th $\neg$ ree Different Loads, International Journal of Maritime Science \& Technology "Our Sea" 66 (1), p. 10-18, 2019. https://doi. org $/ 10.17818 / \mathrm{nm} / 2019 / 1.2$

[7] Fernández, I. A., Gómez, M. R., Gómez, J. R., Insua, A. A. B.: Review of propulsion systems on LNG carriers, Renewable and Sustainable Energy Reviews 67, p. 1395-1411, 2017. https://doi.org/10.1016/j.rser.2016.09.095

[8] Mrzljak, V., Poljak, I., Prpić-Oršić, J.: Exergy analysis of the main propulsion steam turbine from marine propulsion plant, Shipbuilding: Theory and Practice of Naval Architecture, Marine Engineering and Ocean Engineering 70 (1), p. 59-77, 2019. https://doi.org/10.21278/brod70105

[9] Behrendt, C., Stoyanov, R.: Operational characteristics of selected marine turbounits powered by steam from auxiliary oil-fired boilers, New Trends in Production Engineering 1 (1), p. 495-501, 2018. https://doi.org/10.2478/ntpe2018-0061

[10] Mrzljak, V., Poljak, I., Mrakovčić, T.: Energy and exergy analysis of the turbogenerators and steam turbine for the main feed water pump drive on LNG carrier, Energy Conversion and Management 140, p. 307-323, 2017. https:// doi.org/10.1016/j.enconman.2017.03.007

[11] http://www.ttk.hr/en/product/steam-turbines/marine-steam-turbines-typettk-vk-e1v/ (accessed: 25.11.2019.)

[12] Mrzljak, V., Poljak, I., Medica-Viola, V.: Dual fuel consumption and efficiency of marine steam generators for the propulsion of LNG carrier, Applied Thermal Engineering 119, p. 331-346, 2017. https://doi.org/10.1016/j. applthermaleng.2017.03.078

[13] Medica-Viola, V., Pavković, B., Mrzljak, V.: Numerical model for on-condition monitoring of condenser in coal-fired power plants, International Journal of Heat and Mass Transfer 117, p. 912-923, 2018. https://doi.org/10.1016/j. ijheatmasstransfer.2017.10.047

[14] Blažević, S., Mrzljak, V., Anđelić, N., Car, Z.: Comparison of energy flow stream and isentropic method for steam turbine energy analysis, Acta Polytechnica 59 (2), p. 109-125, 2019. https://doi.org/10.14311/ap.2019.59.0109

[15] Ahmadi, G. R., Toghraie, D.: Energy and exergy analysis of Montazeri Steam Power Plant in Iran, Renewable and Sustainable Energy Reviews 56, p. 454463, 2016. https://doi.org/10.1016/j.rser.2015.11.074

[16] Lemmon, E.W., Huber, M.L., McLinden, M.O.: NIST reference fluid thermodynamic and transport properties-REFPROP, version 9.0, User's guide, Colorado, 2010. 
[17] Moran M., Shapiro H., Boettner, D. D., Bailey, M. B.: Fundamentals of engineering thermodynamics, Seventh edition, John Wiley and Sons, Inc., 2011.

[18] Mrzljak, V., Blecich, P., Anđelić, N., Lorencin, I.: Energy and Exergy Analyses of Forced Draft Fan for Marine Steam Propulsion System during Load Change, Journal of Marine Science and Engineering 7 (11), 381, 2019. https://doi. org/10.3390/jmse7110381

[19] Koroglu, T., Sogut, O. S.: Advanced exergy analysis of an organic Rankine cycle waste heat recovery system of a marine power plant, Journal of Thermal Engineering 3 (2), p. 1136-1148, 2017. https://doi.org/10.18186/ thermal.298614

[20] Dorosz, P., Wojcieszak, P., Malecha, Z.: Exergetic Analysis, Optimization and Comparison of LNG Cold Exergy Recovery Systems for Transportation, Entropy 20 (1), 59, 2018. https://doi.org/10.3390/e20010059

[21] Ahmadi, G., Toghraie, D., Akbari, O. A.: Solar parallel feed water heating repowering of a steam power plant: A case study in Iran, Renewable and Sustainable Energy Reviews 77, p. 474-485, 2017. https://doi.org/10.1016/j. rser.2017.04.019

[22] Mrzljak, V., Prpić-Oršić, J., Senčić, T.: Change in Steam Generators Main and Auxiliary Energy Flow Streams During the Load Increase of LNG Carrier Steam Propulsion System, Scientific Journal of Maritime Research 32 (1), p. 121-131, 2018. https://doi.org/10.31217/p.32.1.15

[23] Noroozian, A., Mohammadi, A., Bidi, M., Ahmadi, M. H.: Energy, exergy and economic analyses of a novel system to recover waste heat and water in steam power plants, Energy Conversion and Management 144, p. 351-360, 2017. https://doi.org/10.1016/j.enconman.2017.04.067

[24] Adibhatla, S., Kaushik, S. C.: Energy and exergy analysis of a super critica thermal power plant at various load conditions under constant and pure sliding pressure operation, Applied Thermal Engineering 73, p. 49-63, 2014 https://doi.org/10.1016/j.applthermaleng.2014.07.030

[25] Mrzljak, V., Poljak, I., Medica-Viola, V.: Thermodynamical analysis of highpressure fed water heater in steam propulsion system during exploitation, Shipbuilding: Theory and Practice of Naval Architecture, Marine Engineering and Ocean Engineering 68 (2), p. 45-61, 2017. https://doi.org/10.21278/ brod68204

[26] Kumar, S., Kumar, D., Memon, R. A., Wassan, M. A., Ali, M. S.: Energy and Exergy Analysis of a Coal Fired Power Plant, Mehran University Research Journal of Engineering \& Technology 37 (4), p. 611-624, 2018. https://doi.org/10.22581/ muet1982.1804.13

[27] Cengel Y., Boles M.: Thermodynamics an engineering approach, Eighth edition, McGraw-Hill Education, 2015

[28] Kanoğlu, M., Çengel, Y.A., Dincer, I.: Efficiency Evaluation of Energy Systems, Springer Briefs in Energy, Springer, 2012. (doi:10.1007/978-1-4614-2242-6)

[29] Koroglu, T., Sogut, O. S.: Conventional and Advanced Exergy Analyses of a Marine Steam Power Plant, Energy 163, p. 392-403, 2018. https://doi. org/10.1016/j.energy.2018.08.119

[30] Lorencin, I., Anđelić, N., Mrzljak, V., Car, Z.: Exergy analysis of marine steam turbine labyrinth (gland) seals, Scientific Journal of Maritime Research 33 (1) p. 76-83, 2019. https://doi.org/10.31217/p.33.1.8

[31] Tan, H., Shan, S., Nie, Y., Zhao, Q.: A new boil-off gas re-liquefaction system for LNG carriers based on dual mixed refrigerant cycle, Cryogenics 92, p. 84-92, 2018. https://doi.org/10.1016/j.cryogenics.2018.04.009

[32] Kowalczyk, T., Ziółkowski, P., Badur, J.: Exergy Losses in the Szewalski Binary Vapor Cycle, Entropy 17, p. 7242-7265, 2015. https://doi.org/10.3390/ e17107242

[33] Mrzljak, V., Poljak, I., Žarković, B.: Exergy Analysis of Steam Pressure Reduction Valve in Marine Propulsion Plant on Conventional LNG Carrier, International Journal of Maritime Science \& Technology "Our Sea" 65 (1), p. 24-31, 2018. https://doi.org/10.17818/nm/2018/1.4
[34] Uysal, C., Kurt, H., Kwak H.-Y.: Exergetic and thermoeconomic analyses of a coal-fired power plant, International Journal of Thermal Sciences 117, p. 106 120, 2017. https://doi.org/10.1016/j.ijthermalsci.2017.03.01

[35] Mrzljak, V., Senčić, T., Žarković, B.: Turbogenerator Steam Turbine Variation in Developed Power: Analysis of Exergy Efficiency and Exergy Destruction Change, Modelling and Simulation in Engineering 2018. https://doi. org/10.1155/2018/2945325

[36] Catrini, P., Cipollina, A., Micale, G., Piacentino, A., Tamburini, A.: Exergy analysi and thermoeconomic cost accounting of a Combined Heat and Power steam cycle integrated with a Multi Effect Distillation-Thermal Vapour Compression desalination plant, Energy Conversion and Management 149, p. 950-965, 2017. https://doi.org/10.1016/j.enconman.2017.04.032

[37] Ziółkowski, P., Kowalczyk, T., Lemański, M., Badur, J.: On energy, exergy, and environmental aspects of a combined gas-steam cycle for heat and power generation undergoing a process of retrofitting by steam injection, Energy Conversion and Management 192, p. 374-384, 2019. https://doi. org/10.1016/j.enconman.2019.04.033

[38] Elčić, Z.: Steam turbines, ABB, Karlovac, National and University Library Zagreb, 1995

[39] Dakshina Murty, V.: Turbomachinery - Concepts, Applications, and Design CRC Press, Taylor \& Francis Group, 2018.

[40] Mrzljak, V.: Low power steam turbine energy efficiency and losses during the developed power variation, Technical Journal 12 (3), p. 174-180, 2018. https:// doi.org/10.31803/tg-20180201002943

[41] McBirnie, S. C.: Marine Steam Engines and Turbines, fourth edition, Butterworth \& Co. Ltd., London, England, UK, 1980.

[42] Elhelw, M., Al Dahma, K. S., Hamid Attia, A. E.: Utilizing exergy analysis in studying the performance of steam power plant at two different operation mode, Applied Thermal Engineering 150, p. 285-293, 2019. https://doi. org/10.1016/j.applthermaleng.2019.01.003

[43] Taylor, D. A.: Introduction to Marine Engineering, Elsevier ButterworthHeinemann, 1998

[44] Hafdhi, F., Khir, T., Ben Yahyia, A., Ben Brahim, A.: Energetic and exergetic analysis of a steam turbine power plant in an existing phosphoric acid factory, Energy Conversion and Management 106, p. 1230-1241, 2015. https://doi. org/10.1016/j.enconman.2015.10.044

[45] Mrzljak, V., Medica, V., Bukovac, O.: Simulation of a two-stroke slow speed diesel engine using a quasi-dimensional model, Transactions of FAMENA 40 (2), p. 35-44, 2016. https://doi.org/10.21278/tof.40203

[46] Baldi, F., Johnson, H., Gabrielii, C., Andersson, K.: Energy and Exergy Analysis of Ship Energy Systems - The Case study of a Chemical Tanker, International Journal of Thermodynamics 18 (2), p. 82-93, 2015. https://doi.org/10.5541/ ijot.5000070299

[47] Cangioli, F., Chatterton, S., Pennacchi, P., Nettis, L, Ciuchicchi, L.:Thermo-elasto bulk-flow model for labyrinth seals in steam turbines, Tribology International 119, p. 359-371, 2018. https://doi.org/10.1016/j.triboint.2017.11.016

[48] Kostyuk, A., Frolov, V.: Steam and gas turbines, Mir Publishers, Moscow 1988.

[49] Kopac, M., Hilalci, A.: Effect of ambient temperature on the efficiency of the regenerative and reheat Catalagzi power plant in Turkey, Applied Thermal Engineering 27, p. 1377-1385, 2007. https://doi.org/10.1016/j. applthermaleng.2006.10.029

[50] Aljundi, I. H.: Energy and exergy analysis of a steam power plant in Jordan, Applied Thermal Engineering 29, p. 324-328, 2009. https://doi.org/10.1016/j. applthermaleng.2008.02.029 